\title{
ПСИХОЛІНГВАЛЬНІ МАРКЕРИ РАННІХ ДИСФУНКЦІЙНИХ СХЕМ У ВЧИТЕЛІВ ІЗ ВИСОКИМ СТУПЕНЕМ ТРУДОГОЛІЗМУ
}

\author{
Ірина Онопченко \\ irynonopchenko@gmail.com \\ Східноєвропейський національний університет імені Лесі Українки, Україна \\ Марина Орап \\ orap2003@ukr.net \\ Тернопільський національний педагогічний університет імені Володимира \\ Гнатюка, Україна \\ Ігор Мудрак \\ sim851@ukr.net \\ Східноєвропейський національний університет імені Лесі Українки, Україна
}

Received October 6, 2019; Revised November 21, 2019; Accepted December 14, 2019

Анотація. У статті відображено результати дослідження психолінгвальних маркерів ранніх дисфункційних схем у вчителів. Дослідження представлене у вигляді багатопланового дослідження із залученням регресійного аналізу, де ранні дисфункційні схеми, психологічне благополуччя, задоволення шлюбом слугують незалежними змінними, а трудоголізм залежною змінною. Після отримання дозволу від Ради з етики наукових досліджень Східноєвропейського національного університету імені Лесі Українки 53 учителі загальноосвітніх шкіл Волинської області (Україна) взяли участь у дослідженні трудоголізму, серед них 50 жінок, 3 чоловіків, середній вік 46,47 ( $\mathrm{SD}=10,17)$, стаж роботи 24,06 ( $\mathrm{SD}=10,97$ ). Опитувальник Янга $Y S Q$ - S3, шкала трудоголізму (Shkoler et al., 2018), шкала задоволеності шлюбом (Столін, Романова, Бутенко), шкала задоволення щоденною працею (Loi et al., 2009), шкала психологічного благополуччя (Ryff \& Keyes, 1995) використовувалися для дослідження трудоголізму та його предикторів у вчителів. Результати засвідчили, що ранні дисфункційні схеми, психологічне благополуччя, задоволеність шлюбом сукупно слугують предикторами трудоголізму у вчителів. Водночас лише ранні дисфункційні схеми є незалежними значущими предикторами трудоголізму. Визначено психолінгвальні маркери ранніх дисфункційних схем, пов'язаних із трудоголізмом. Високорозвинений трудоголізм у вчителів пов'язаний із очікуванням на катастрофу, страхом покарання і негативізмом, уявленням про власну некомпетентність і невдачу, пошуком визнання й високих стандартів. Важливим прикладним висновком дослідження $\epsilon$ можливість використання психолінгвістичних маркерів для визначення ранніх дисфункційних схем, пов'язаних із трудоголізмом у вчителів.

Ключові слова: трудоголізм вчителів, ранні дисфункиійні схеми, психологічне благополуччя, задоволення щуоденною працею, задоволення шлюбом, психолінгвальні маркери.

Onopchenko, Iryna; Orap, Maryna; Mudrak, Ihor. Psycholinguistic Markers of Early Maladaptive Schemas in Teachers with High Prevalence of Workaholism.

Abstract. This study examines psycholinguistic markers of early maladaptive schemas in teachers with high prevalence of workaholism. The study represents the cross-sectional, between

\footnotetext{
(C) Онопченко Ірина, Орап Марина, Мудрак Ігор, 2019. This is an Open Access article distributed under the terms and conditions of the Creative Commons Attribution 4.0 International Licence (http://creativecommons.org/ licenses/by/4.0).

East European Journal of Psycholinguistics, 6(2), 80-88. https://doi.org/10.5281/zenodo.3637741
} 
subjects design utilizing the independent variables of early maladaptive schemas, psychological wellbeing, daily job satisfaction, satisfaction of marriage and dependent variable of workaholism in teachers. The approval letter to recruit the participants from secondary schools in Volyn Oblast, Ukraine in 2018-2019 academic year was obtained from the Research Ethics Committee at Lesya Ukrainka Eastern European National University. 53 teachers, females $(n=50)$, males $(n=3)$, mean age was 46.47 ( $\mathrm{SD}=10.17)$, seniority was 24.06 ( $\mathrm{SD}=10.97)$ were recruited. Young Schema Questionnaire, Version 3 (YSQ - S3), The Workaholism Facet-Based Scale (Shkoler et al., 2018), Satisfaction of Marriage Scale (Stolin et al., 1984), Daily Job Satisfaction Scale методика задоволення щоденною роботою (Loi et al., 2009), Ryff's Scale of Psychological Well-Being assess workoholism and its relations with well-being and satisfaction in teachers. The results indicate that early maladaptive schemas, psychological well-being, satisfaction of marriage taken together are predictors of workaholism. However, early maladaptive schemas are the only independent significant predictors of workaholism in teachers. The most frequent statements as psycholinguistic markers of developed early maladaptive schemas in teachers with high prevalence of workaholism are examined. The high prevalence of workaholism in teachers is associated with vulnerability to harm or illness; self-sacrifice; unrelenting standards and hypocriticalness; approval and recognition seeking; negativity and punitiveness. The principal implication of this study is that early maladaptive schemas might be examined through psycholinguistic markers represented by frequent verbal statements of teachers with high prevalence of workaholism.

Keywords: workaholism in teachers, early maladaptive schemas, psychological well-being, daily job satisfaction, satisfaction of marriage, psycholinguistic markers.

\section{1. Вступ}

Життя сучасної людини сповнене значною кількістю соціальних змагань, які регулюються механізмом соціального порівняння. До таких змагань належать академічні випробування, спортивні змагання, конкуренція у професійних відносинах на робочому місці і т.ін. За таких умов, на думку Braslow et al. (2012), участь у таких змаганнях часто породжує сумніви стосовно власної компетентності, знижує рівень домагань та погіршує уявлення про власні здібності у професійному середовищі. За результатами дослідження Mir \& Kamal (2018), близько 70 \% досліджуваних засвідчили наявність сумнівів стосовно власної компетентності під час виконання професійних завдань у різні періоди свого життя. Сумніви стосовно власної компетентності отримали в зарубіжній літературі назву імпостерних емоцій та імпостерного феномену. Clance \& Imes (1978) ввели ці поняття у науковий обіг у 1978 році, дослідивши студенток коледжу, які не вірили у можливість власних досягнень і власні здібності. Відтоді імпостерні емоції тлумачаться як наявність сумнівів стосовно власної компетентності i можливості досягнень. Учені визначили кілька аспектів у цьому конструкті: відчуття інтелектуального шахрайства (випадковості досягнень); відчуття, що досягнення - це результат наполегливої роботи, а не власних здібностей; брак упевненості повторити попередні досягнення; страх зазнати поразку в майбутньому, мати низькі досягнення, і бути негативно оціненими; втрата задоволення від досягнень; страх бути оціненим як некомпетентний (Braslow et al., 2012).

На думку Mir \& Kamal (2018), проблемою в дослідженні імпостерних емоцій $\epsilon$ відсутність діагностичного інструментарію. На нашу думку, 
дослідження імпостерних емоцій, що зіставляються із сумнівами щодо власної компетентності, може грунтуватися на підході Дж. Янга, який був названий схема-терапією (Young, 1999). Схема-терапія була розроблена як модифікація когнітивно-поведінкової терапії (КПТ) для клієнтів, з якими стандартна КПТ була недостатньо ефективною, та поєднує у собі елементи КПТ, гештальттерапії, елементи психоаналітичної та конструктивістської шкіл психології.

Основні теоретичні елементи в концепції схема-терапії - базові емоційні потреби; ранні дисфункційні схеми; дисфункційні копінг-стратегії; режими функціонування схем (дисфункційні режими).

Ранні дисфункційні схеми - це негативні життєві схеми (патерни) сприйняття, емоційного реагування та фізичних відчуттів, які формуються у дитинстві внаслідок дисфункційної взаємодії із важливими для особи людьми. Ці схеми, формуючись у дитинстві, продовжують розвиватися протягом життя, та відображаються на житті особи навіть у тих випадках, коли вони $є$ неефективними.

Дж. Янг виділив 18 ранніх дисфункційних схем, диференційованих на 5 груп (табл. 1).

Таблиця 1

Ранні дисфункиійні схеми

\begin{tabular}{ll}
\hline \multicolumn{1}{c}{ Група схем } & \multicolumn{1}{c}{ Схема } \\
\hline 1. Порушення зв’язку та & 1.1. Відкинутість/Нестабільність \\
відкинення & 1.2. Недовіра/ Очікування жорстокого поводження \\
& 1.3. Емоційна депривованість \\
& 1.4. Дефективність/Сором \\
& 1.5. Соціальна відстороненість \\
2. Порушена автономія & 2.1. Залежність/Некомпетентність \\
& 2.2. Вразливість/Катастрофізація \\
& 2.3. Залежність/Нерозвинена ідентичність \\
& 2.4. Некомпетентність/Очікування на невдачу \\
3. Порушені межі & 3.1. Привілейованість/Особливий статус \\
& 3.2. Нестача самоконтролю \\
4. Спрямованість на & 4.1. Покірність \\
інших & 4.2. Самопожертва \\
& 4.3. Пошук схвалення \\
5. Надмірна пильність та & 5.1. Негативізм/Песимізм \\
заборони & 5.2. Пригнічення емоцій \\
& 5.3. Жорсткі стандарти \\
& 5.4. Очікування на покарання \\
\hline
\end{tabular}

Як видно з таблиці, імпостерні емоції безпосередньо пов'язані зі сферами порушеної автономії, спрямованості на інших та надмірної пильності й заборони. Відповідно, важливими схемами в цьому контексті $\epsilon$ схеми залежності і некомпетентності, пошуку визнання, жорсткі стандарти. 
Дослідження цих схем викликають неабиякий інтерес у контексті трудоголізму. Уперше трудоголізм як клінічний феномен було описано американським психологом та релігійним проповідником В. Оутсом у 1971 році (Oates, 1971). Він не тільки ввів термін «трудоголізм» в обіг, а й описав ознаки цієї поведінкової залежності. На думку Oates (1971), трудоголіки - це особи, які відчувають психологічну залежність від роботи та компульсивну потребу працювати. У сучасній літературі визначено три компоненти трудоголізму. До них належать когнітивний компонент (когнітивні процеси, які обумовлюють залежність людини від роботи); афективний компонент (сукупність емоцій i почуттів, які супроводжують трудоголізм); поведінковий компонент (надлишкове включення в роботу, яке зумовлює руйнацію особистого і професійного життя). Згодом у літературі було визначено два аспекти трудоголізму: надлишкова робота та компульсивна робота (Braslow et al., 2012).

\section{2. Методи дослідження}

Метою дослідження є дослідити на теоретичному і емпіричному рівнях взаємозв'язок ранніх дисфункційних схем та трудоголізм у вчителів, а також установити психолінгвальні маркери ранніх дисфункційних схем, пов'язаних із трудоголізмом.

Шкала трудоголізму в адаптації I. Онопченко, опитувальник YSQ - S3 в адаптації М. Падун, методика психологічного благополуччя К. Ріфф, а також шкала задоволеності шлюбом (В. Столін, Т. Романова, Г. Бутенко) і шкала щзоденного задоволення праџею (Loi et al., 2009) використовувалися у дослідженні.

Апробація опитувальника Шкала трудоголізму проводилася на базі Східноєвропейського національного університету імені Лесі Українки впродовж 2019 року із урахуванням основних психометричних вимог щодо стандартизації та апробації психологічних методик. Опитувальник «Шкала трудоголізму» володіє високим рівнем психометричних характеристик: коефіцієнт а-Кронбаха складає 0,712 , що говорить про високий рівень узгодженості методики.

Шкала трудоголізму містить наступні субшкали:

1. alb1 - поєднання когнітивної модальності із ресурсом часу;

2. alb2 - поєднання когнітивної модальності із ресурсом зусиль;

3. a2b1 - поєднання емоційної модальності із ресурсом часу;

4. a2b2 - поєднання емоційної модальності із ресурсом зусиль;

5. a3b1 - поєднання інструментальної модальності із ресурсом часу;

6. a3b2 - поєднання інструментальної модальності із ресурсом зусиль.

Методика YSQ-S3 апробована у багатьох країнах на клінічних вибірках та має високий рівень психометричних характеристик. Субшкали опитувальника мають високу внутрішню консистентність та надійність. Значення коефіцієнта а-Кронбаха: від 0,68 до 0,96. Також було встановлено, що методика здатна оптимально диференціювати опитуваних за критерієм особистісної тривожності - особи, що мають яскраво виражені ознаки дисфункційних схем демонструють високий рівень тривожності. Методика 
“YSQ-S3" складається із 90 запитань, респондентам пропонується оцінити, наскільки кожне із тверджень опитувальника відповідає їм за допомогою шестибальної шкали Лайкерта. Для інтерпретації результатів обраховується сума оцінок за кожною із 18 шкал методики.

Шкала щуоденного задоволення пращею (Loi et al., 2009) містить три твердження стосовно задоволення роботою, які оцінюються за шкалою від 1 до 6 , де 1 - зовсім незадоволений, 6 - максимально задоволений. Максимальна кількість балів 18. Значення коефіцієнта а-Кронбаха 0,86.

Опитувальник задоволеності шлюбом (В. Столін, Т. Романова, Г. Бутенко) складається 324 тверджень, які групуються у такі аспекти: порівняння свого шлюбу 3 іншими шлюбами; припущення про оцінку власного шлюбу з боку інших; вираження почуттів стосовно партнера; оцінка дружини; настанова на зміну характеру чоловіка; думка стосовно шлюбу загалом. Максимально благополучні відносини оцінюються в 48 балів.

Шкали психологічного благополуччя (ШПБ) - це адаптований україномовний варіант опитувальника "The scales of psychological well-being" (Ryff \& Keyes, 1995) та адаптованого С. Карскановою.

Оригінальна методика пройшла стандартні психометричні процедури перевірки надійності і валідності, більше того окрім процедури ретестування, була досліджена внутрішня узгодженість для кожної шкали, при цьому значення коефіцієнта альфи коливалося від 0,83 до 0,91. Пропонується обрахування балів за конкретними шкалами (максимально 49 балів): позитивні відносини з іншими, автономія, управління середовищем, особистісне зростання, цілі у житті, самоприйняття, а також сумарний бал, що означає психологічне благополуччя загалом (максимально 294 балів).

У дослідженні було поставлено такі дослідницькі питання:

1. Чи існують кореляційні зв'язки між показниками трудоголізму та ранніх дисфункційних схем?

2. Чи можуть ранні дисфункційні схеми, психологічне благополуччя, задоволення шлюбом, задоволення щоденною працею бути незалежними предикторами трудоголізму у вчителів?

3. Чи існують психолінгвістичні маркери ранніх дисфункційних схем, пов'язаних із трудоголізмом?

Дослідження проводилося на базі Луцького ліцею №3, Луцької гімназії №18 та Луцької загальноосвітньої школи №23. В опитуванні взяло участь 53 вчителя віком від 26 до 64 років зі стажем роботи від 4 до 44 років. Середній вік опитуваних становить 45 років, а середній стаж роботи - 24 роки. В переважній більшості опитувані були заміжніми жінками (99 \% жінки, $96 \%$ - у шлюбі). Усі опитувані працювали повний робочий день та мали як мінімум 18 робочих годин на тиждень.

\section{3. Обговорення результатів}

Оскільки вибірка містить понад 30 осіб, відповідно до Центральної граничної теореми $(\mathrm{n}=53>30)$ i першого дослідницького питання, було використано кореляцію Пірсона. Результати кореляційного аналізу відображено в табл. 2. 


\section{Таблиця 2}

Результати корелящійного аналізу показників трудоголізму та ранніх дисфункиійних схем у вчителів

\begin{tabular}{|c|c|c|c|c|c|c|c|}
\hline 声 & 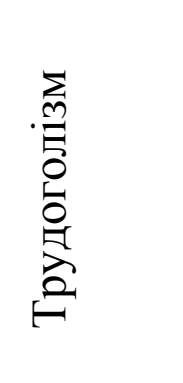 & 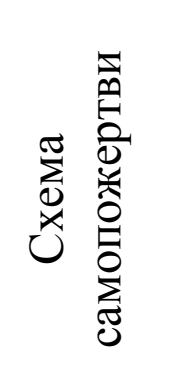 & 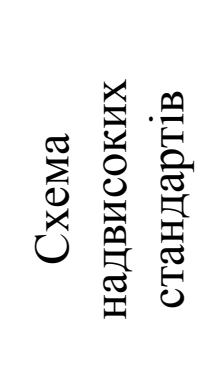 & 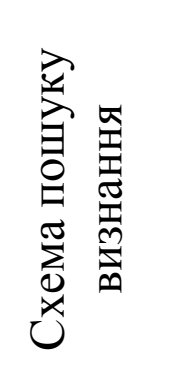 & 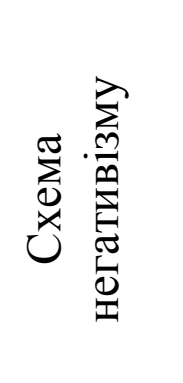 & 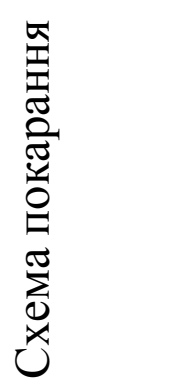 & 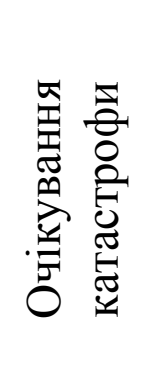 \\
\hline Трудоголізм & . & $0,412 * *$ & & $0,305 * *$ & $0,310 * *$ & $0,432 * *$ & $0,282 *$ \\
\hline $\begin{array}{l}\text { Схема } \\
\text { самопожертви }\end{array}$ & $0,412 * *$ & - & $0,691 * *$ & $0,546 * *$ & $0,575^{* *}$ & $0,481 * *$ & $0,419 * *$ \\
\hline $\begin{array}{l}\text { Схема } \\
\text { надвисоких } \\
\text { стандартів }\end{array}$ & $0,394 * *$ & $0,691 * *$ & - & $0,419 * *$ & $0,529 * *$ & $0,653 * *$ & $0,546^{* *}$ \\
\hline $\begin{array}{l}\text { Схема пошуку } \\
\text { визнання }\end{array}$ & $0,305^{* *}$ & $0,546 * *$ & 0,419 & - & $0,567 * *$ & $0,529 * *$ & $0,462 * *$ \\
\hline $\begin{array}{l}\text { Схема } \\
\text { негативізму }\end{array}$ & $0,310 * *$ & $0,575^{* *}$ & $0,529 * *$ & $0,567 * *$ & - & $0,828 * *$ & $0,741 * *$ \\
\hline $\begin{array}{l}\text { Схема } \\
\text { покарання }\end{array}$ & $0,432 * *$ & $0,481 * *$ & $0,653 * *$ & $0,529 * *$ & $0,828 * *$ & & $0,634 * *$ \\
\hline $\begin{array}{l}\text { Схема } \\
\text { катастрофи }\end{array}$ & $0,282 *$ & $0,419 * *$ & $0,546^{* *}$ & $0,462 * *$ & $0,741 * *$ & $0,634 * *$ & - \\
\hline
\end{tabular}

Примітка. ${ }^{*} \mathrm{p}<0,05 ; * * \mathrm{p}<0,01$

Як видно з таблиці, існують значущі кореляційні зв'язки між трудоголізмом та такими ранніми дисфункційними схемами, як схема вразливості до небезпеки і катастрофізація, схема самопожертви, схема пошуку визнання, та схема очікування на покарання. Отже, отримані результати підтверджують думку про те, що причиною трудоголізму є імпостерні емоції як уявлення про власну некомпетентність і очікування невдачі.

Аби дослідити предиктори трудоголізму, було використано регресійний аналіз, в якому трудоголізм слугував залежною змінною, а ранні дисфункційні схеми, психологічне благополуччя та задоволення шлюбом слугували незалежними змінними.

Результати регресійного аналізу свідчать про те, що ранні дисфункційні схеми, психологічне благополуччя та задоволення шлюбом разом у сукупності слугують предикторами трудоголізму. Ці три змінні пояснюють $18.0 \%, R^{2}=.180$, $F(3.49)=3.58, p=.020$. Результати також свідчать про те, що тільки ранні дисфункційні схеми $є$ незалежним значущим предиктором трудоголізму, $b=.059, t(53)=2.26, p=.028$ (табл. 3$)$. 


\section{Таблиця 3}

Результати регресійного аналізу трудоголізму, ранніх дисфункиійних схем, психологічного благополуччя та задоволення шлюбом

\begin{tabular}{llllrr}
\hline \multicolumn{1}{c}{ Змінні } & \multicolumn{1}{c}{ В } & SEB & $\beta$ & $\mathrm{t}$ & $\mathrm{p}$ \\
\hline Ранні & 0,059 & 0,026 & 0,43 & 2,61 & 0,028 \\
дисфункційні & $(0,007$, & & & & \\
схеми & $0,112)$ & & & & \\
Психологічне & 0,075 & 0,42 & 0,323 & 1,796 & 0,079 \\
благополуччя & $\begin{array}{l}0,009, \\
\text { 0,054) }\end{array}$ & & & & \\
Задоволеність & 0,129 & & & & \\
шлюбом & $(-0,118$, & $-0,129$ & $-0,232$ & $-1,590$ & 0,118 \\
& $-0,464)$ & & & & \\
\hline
\end{tabular}

Отже, результати регресійного аналізу свідчать про те, що ранні дисфункційні схеми $\epsilon$ значущим предиктором трудоголізму, зокрема схема некомпетентності, що наближує предиктори трудоголізму до імпостерних емоцій.

Психолінгвальні маркери ранніх дисфункційних схем, пов'язаних із трудоголізмом, відображено в табл. 4.

\section{Таблиця 4}

Психолінгвальні маркери ранніх дисфункційних схем, пов 'язаних із трудоголізмом

Ранні дисфункційні схеми

Схема некомпетентності

Схема очікування на катастрофу

Схема очікування на покарання

Схема пошуку визнання

\section{Психолінгвістичні маркери}

Я нічого не роблю так добре, як інші; я справді некомпетентний, якщо оцінювати мої здібності у житті; інші люди є здібнішими за мене

Маю відчуття, що трапиться щось погане; на мене хтось нападе; я можу все втратити; у мене може розвинутися серйозна хвороба Якщо я помилюся, мене покарають; я несу велику відповідальність за кожну свою помилку

Гроші і знайомства надають мені важливості; досягнення мають сенс, якщо їх помічають; я почуваюся меншовартісним, якщо не отримую належної уваги з боку інших 


\section{4. Висновки}

Результати дослідження дають змогу встановити тісний кореляційний зв’язок між ранніми дисфункційними схемами й трудоголізмом. Більш того, ранні дисфункційні схеми слугують незалежним значущим предиктором трудоголізму. Особливої значущості набувають схеми очікування на катастрофу, пошук визнання, схема некомпетентності та очікування на невдачу і вірогідність покарання. Установлення психолінгвальних маркерів ранніх дисфункційних схем можуть слугувати важливим діагностичним інструментом імпостерних емоцій та уявлень про власну некомпетентність у вчителів із розвиненим трудоголізмом.

\section{Лiтература}

\section{References}

Онопченко I. В. Психологічна валідизація і культурна адаптація опитувальника "Тhe Workaholism Facet-Based Scale" (WFBS) // Наукові записки Національного університету «Острозька академія». Серія «Психологія». 2019. Вип. 9. С. 107-117.

Braslow, M. D., Guerrettaz, J., Arkin, R. M., \& Oleson, K. C. (2012). Self-doubt. Social and Personality Psychology Compass, 6(6), 470-482.

Clance, P. R., \& Imes, S. A. (1978). The imposter phenomenon in high achieving women: Dynamics and therapeutic intervention. Psychotherapy: Theory, Research \& Practice, 15(3), 241.

Mir, I., \& Kamal, A. (2018). Role of workaholism and self-concept in predicting impostor feelings among employees. Pakistan Journal of Psychological Research, 33(2), 413-427.

Oates, W. E. (1971). Confessions of a Workaholic: The Facts About Work Addiction. N. Y.: World Publishing Company.

Ryff, C. D., \& Keyes, C. L. M. (1995). The structure of psychological well-being revisited. Journal of Personality and Social Psychology, 69(4), 719-727.

Young, J. E. (1999). Cognitive Therapy for Personality Disorders: A Schema-Focused Approach. Professional Resource Press/Professional Resource Exchange.

\section{References (translated and transliterated)}

Onopchenko, I. (2019). Psykholohichna validyzatsiya i kulturna adaptatsiia opytuvalnyka The Workaholism Facet-Based Scale (WFBS). Naukovi Zapyski of the Ostroh Academy National University. Psychology Series, 9, 107-117.

Braslow, M. D., Guerrettaz, J., Arkin, R. M., \& Oleson, K. C. (2012). Self-doubt. Social and Personality Psychology Compass, 6(6), 470-482.

Clance, P. R. \& Imes, S. A. (1978). The imposter phenomenon in high achieving women: Dynamics and therapeutic intervention. Psychotherapy: Theory, Research \& Practice, 15(3), 241.

Mir, I. \& Kamal, A. (2018). Role of workaholism and self-concept in predicting impostor feelings among employees. Pakistan Journal of Psychological Research, 33(2), 413-427.

Oates, W. E. (1971). Confessions of a Workaholic: The Facts About Work Addiction. N. Y.: World Publishing Company.

Ryff, C. D., \& Keyes, C. L. M. (1995). The structure of psychological well-being revisited. Journal of Personality and Social Psychology, 69(4), 719-727. 
Young, J. E. (1999). Cognitive Therapy for Personality Disorders: A Schema-Focused Approach. Professional Resource Press/Professional Resource Exchange. 